\title{
Identification and Functional
} Characterization of Sugarcane Invertase Inhibitor (ShINH1): A Potential Candidate for Reducing Pre- and Post-harvest Loss of Sucrose in Sugarcane

\author{
Suresha G. Shivalingamurthy ${ }^{1,2}$, Raveendra Anangi ${ }^{3}$, Sundaravelpandian Kalaipandian ${ }^{1}$, \\ Donna Glassop ${ }^{1}$, Glenn F. King ${ }^{3}$ and Anne L. Rae ${ }^{1 *}$ \\ ${ }^{1}$ CSIRO Agriculture and Food, St Lucia, QLD, Australia, ${ }^{2}$ ICAR-Sugarcane Breeding Institute, Coimbatore, India, ${ }^{3}$ Division of \\ Chemistry and Structural Biology, Institute for Molecular Bioscience, The University of Queensland, St Lucia, QLD, Australia
}

\section{OPEN ACCESS}

Edited by:

Jens Rohloff,

Norwegian University of Science and

Technology, Norway

Reviewed by:

Leila Priscila Peters,

Universidade de São Paulo, Brazil

Javad Najafi,

Norwegian University of Science and

Technology, Norway

*Correspondence:

Anne L. Rae

Anne.Rae@csiro.au

Specialty section:

This article was submitted to Plant Metabolism and Chemodiversity, a section of the journal

Frontiers in Plant Science

Received: 13 January 2018 Accepted: 16 April 2018 Published: 03 May 2018

Citation:

Shivalingamurthy SG, Anangi $R$, Kalaipandian S, Glassop D, King GF and Rae AL (2018) Identification and

Functional Characterization of

Sugarcane Invertase Inhibitor (ShINH1): A Potential Candidate for Reducing Pre- and Post-harvest Loss of Sucrose in Sugarcane.

Front. Plant Sci. 9:598.

doi: 10.3389/fpls.2018.00598
In sugarcane, invertase enzymes play a key role in sucrose accumulation and are also involved in futile reactions where sucrose is continuously degraded during the pre- and post-harvest period, thereby reducing sugar yield and recovery. Invertase inhibitor $(\mathrm{INVINH)}$ proteins play a key role in post-translation regulation of plant invertases through which sucrose hydrolysis is controlled. INVINH proteins are small (18 kDa) members of the pectin methylesterase inhibitor superfamily and they are moderately conserved across plants. In the present study, we identified two INVINH genes from sugarcane, ShINH1 and ShINH2. In silico characterization of the encoded proteins revealed $43 \%$ sequence identity at the amino acid level, confirming the non-allelic nature of the proteins. The presence of putative signal peptide and subcellular targeting sequences revealed that ShINH1 and ShINH2 likely have apoplasmic and vacuolar localization, respectively. Experimental visualization of ShINH1-GFP revealed that ShINHI is indeed exported to the apoplast. Differential tissue-specific and developmental expression of ShINH1 between leaf, stalk, flower and root suggest that it plays a role in controlling source-sink metabolic regulation during sucrose accumulation in sugarcane. ShINH1 is expressed at relatively high levels in leaves and stalk compared to flowers and roots, and expression decreases significantly toward internodal maturity during stalk development. ShINH1 is expressed at variable levels in flowers with no specific association to floral maturity. Production of recombinant ShINH1 enabled experimental validation of protein function under in vitro conditions. Recombinant ShINH1 potently inhibited acid invertase $\left(\mathrm{IC}_{50} 22.5 \mathrm{nM}\right)$, making it a candidate for controlling pre- and post-harvest deterioration of sucrose in sugarcane. Our results indicate that ShINH1 and ShINH2 are likely to play a regulatory role in sucrose accumulation and contribute to the improvement of sugar yield and recovery in sugarcane.

Keywords: INVINH proteins, heterologous expression, functional identity, sucrose accumulation, post-harvest deterioration, sugar yield 


\section{INTRODUCTION}

Sugarcane (Saccharum spp.) is the major source of sucrose worldwide. Annually, 1,800 million tons of cane produced in an area of 27 Mha contributes $\sim 80 \%$ of world sugar production (FAOSTAT, 2014). Sucrose metabolism is a complex process in sugarcane involving transfers between a number of compartments for synthesis, transport, and accumulation. The major source tissue for sucrose synthesis is mature leaves and sucrose is subsequently transported to sinks including growing points and the storage tissues of mature internodes where it may be further metabolized or accumulated. The net amount of sucrose accumulated in the storage parenchyma of the stalk depends on the balance between sucrose synthesis and breakdown activities (Moore, 1995). A remarkable feature of sugarcane is its capacity to store sucrose to about $50 \%$ of its dry weight. However, at crop maturity when the sucrose concentration in the sink tissues reaches saturation, the action of invertase enzymes affects sucrose stabilization, and reduces sucrose yield (Chandra et al., 2012). Also during the postharvest period, activation of endogenous invertase enzymes leads to deterioration of sucrose in the cut cane and ultimately low sugar recovery (Solomon, 2009). Thus, sucrose breakdown by invertases causes a major economic loss to farmers and sugar processors. The rise in invertase activity and consequent loss of sucrose become increasingly problematic as the time gap between harvesting and milling increases. Singh et al. (2008) reported a 1.38- and 4.75-fold increase in invertase activity after 48 and $240 \mathrm{~h}$ of standing post-harvest, respectively, as compared to the initial activity in freshly cut cane. When milling of the cane cannot be completed within a day of cutting, other approaches are needed to preserve sucrose content. Suppression of invertase activity to stabilize sucrose content at cane maturity and after harvest has been investigated as a possible solution (Solomon, 2009).

Invertases [EC 3.2.1.26; $\beta$-fructosidase] are a family of enzymes known to perform diverse functions in plants in addition to hydrolysis of sucrose into glucose and fructose. In sugarcane, invertases are mainly involved in regulation of sucrose accumulation and plant development. (Moore, 1995; Zhu et al., 1997). Sucrose unloaded from the phloem in the sugarcane stalk is transported to three different cellular compartments: the apoplastic space (cell wall), cytoplasm, and vacuole (Bieleski, 1960; Hatch and Glasziou, 1963; Sacher et al., 1963; Ma et al., 2000). Each compartment has a specific invertase isoform: an apoplastic space located cell wall invertase (CWI), a vacuolar located acid invertase (VAI) also termed a soluble acid invertase (SAI), and a cytoplasmic located neutral invertase (NI) (Ma et al., 2000). Sucrose accumulated in sugarcane stalks is probably resynthesized from the hydrolysis products of translocated sucrose following breakdown by invertase enzymes (Hatch and Glasziou, 1963; Ma et al., 2000). Sucrose synthase (SuSy) and invertases are involved in futile cycling during the process of sugar transport between cytoplasm, vacuole and cell wall, which is sometimes energetically wasteful (Botha et al., 2001) due to continuing sucrose hydrolysis and resynthesis. In this way sucrose/hexose interchange determines net sucrose content in sugarcane juice. The major function of invertases is to maintain high hexose concentration, and the hydrolysis of sucrose in the vacuole and in the intracellular space affects the sucrose yield in sugarcane (Whittaker and Botha, 1997; Wu and Birch, 2007; Wang et al., 2013). Because most previous studies have focused on SAI, the role of other sugarcane invertase isoforms in regulation of sucrose accumulation is poorly understood. (Ma et al., 2000; Botha et al., 2001; Chandra et al., 2012). Thus, there is a need for further information on sugarcane invertases before specific strategies for manipulation can be defined.

Invertase has been a target for molecular manipulation to alter carbohydrate accumulation in a number of plants, including Arabidopsis (von Schaewen et al., 1990), tobacco (Sonnewald et al., 1991), tomato (Ohyama et al., 1995), potato (Bussis et al., 1997), and carrot (Tang et al., 1999). There have been efforts to control invertase enzymes (both SAI and NI) in sugarcane through transgenesis but despite producing successful transgenic events, there was no significant increase in overall sucrose yield (Ma et al., 2000; Botha et al., 2001; Rossouw et al., 2007). This may be due to regulatory feedback between sink and source during sucrose accumulation (McCormick et al., 2006, 2009; Chandra et al., 2011). In the light of these results, novel avenues are needed to manipulate plant invertases and study the possible effects on sucrose content in sugarcane. Post-translational silencing of invertase enzymes using specific inhibitor proteins is an approach that has not previously been tested.

The extent of proteolytic degradation of invertases depends on non-covalent complex formation with invertase inhibitor (INVINH) proteins (Rausch and Greiner, 2004). The first plant INVINH was discovered in potato, with homologs subsequently identified in red beet, sugar beet, sweet potato and maize (Schwimmer et al., 1961; Pressey, 1968; Jaynes and Nelson, 1971; Kursanov et al., 1971). The first gene encoding an INVINH protein was cloned from tobacco (Nicotiana tabacum), and the recombinant protein was shown to be an effective inhibitor of invertase activity in vitro (Greiner et al., 1998). Overexpression of the tobacco gene in potato reduced invertase activity in vivo and suppressed cold-induced sweetening of tubers (Greiner et al., 1999). Further studies showed the attenuation of apoplastic INVINH activity by sucrose. The results suggested that sink strength and partitioning may be controlled by a regulatory mechanism involving three components: invertase, inhibitor, and sucrose (Sander et al., 1996; Krausgrill et al., 1998). The first monocot INVINH gene was cloned from maize, where it was found to be expressed during early kernel development and involved in regulation of endosperm formation by inhibiting apoplasmic invertase (Bate et al., 2004).

Manipulation of specific invertase inhibitor genes by overexpression or silencing has been tested in a range of plants as a strategy for modulating invertase activity. In addition to the intended target of sucrose metabolism, these approaches can also affect other physiological processes including seed development, leaf senescence, and responses to both biotic and abiotic stresses. For example, Jin et al. (2009) showed that inhibition of the CWI in tomato by the INVINH1 inhibitor regulated leaf senescence and the development of seeds and fruits. Similarly, in soybean, silencing of the GmCIF1 inhibitor lead to increased activity of 
CWI which modified sucrose metabolism and sink strength and enhanced the maturation of seeds (Tang et al., 2017). Embryo growth may also be impacted by modulation of invertase inhibitors, since an important role for an endosperm-expressed INVINH in Arabidopsis was recently demonstrated (Zuma et al., 2018). It has been shown that invertases are involved in regulation of stomatal opening $(\mathrm{Ni}, 2012)$ and ectopic expression of a tobacco vacuolar invertase inhibitor in Arabidopsis changed stomatal function resulting in improved drought tolerance (Chen et al., 2016). Enhanced cold tolerance in tomato was achieved through silencing of the INVINH1 inhibitor which caused an increase in the activity of CWI (Xu et al., 2017).

Given the potential of INVINH proteins in controlling invertase activity, we performed the first exploration of the sugarcane genome for INVINH genes. This led to identification, cloning and characterization of two sugarcane INVINH genes, ShINH1 and ShINH2. We completed a functional characterization of ShINH1, demonstrating temporal and spatial expression, subcellular localization in a heterologous system, and invertase inhibitory activity of recombinant ShINH1. This is the first study where the functional identity of a sugarcane INVINH gene has been established by evaluating the inhibitory activity against invertase. The results of this study will underpin future efforts to control invertase-induced losses of sucrose in post-harvest sugarcane.

\section{MATERIALS AND METHODS}

\section{Plant Material and Growth Conditions}

The Saccharum hybrid cultivar Q208 was used for all experiments. This variety was selected for experiments due to its wide adaptability and highest tonnage among the cultivated varieties in Australia (https://sugarresearch.com.au).

Individual plantlets, arising from single bud setts of Saccharum hybrid Q208 were germinated in vermiculite, and were transplanted to $8 \mathrm{~L}$ pots containing Searles Peat 80 Mix (Searles, Australia). Setts were germinated monthly to produce a series of plants with different ages from 5 to 8 months (March, 5th month: 150 DAP); April, 6th month: 180 DAP; May, 7th month: 210 DAP and June, 8th month: 240 DAP). Plant growth conditions consisted of $14 \mathrm{~h}$ light $\left(500 \mu \mathrm{mol}\right.$ photons $\left.\mathrm{m}^{-2} \mathrm{~s}^{-1}\right)$ conditions at $30^{\circ} \mathrm{C} / 55 \%$ temperature and humidity, respectively, and $10 \mathrm{~h}$ dark conditions at $24^{\circ} \mathrm{C} / 65 \%$; with daily watering. Internodes were numbered according to previously published research whereby the first top leaf with a visible dewlap is attached to internode 1 (Kuijper, 1915; Moore, 1987). During harvesting, internodes 4 (young immature), 8 (moderately mature), and 13 (fully mature) were cut into $1 \mathrm{~cm}$ cubes and immediately frozen in liquid $\mathrm{N}_{2}$ and then stored at $-80^{\circ} \mathrm{C}$. Frozen samples were ground into a fine powder using a ball mill (MM400, Retsch, Germany) at $30 \mathrm{~Hz}$ for $2 \mathrm{~min}$. The powdered samples were dried using a vacuum freeze drier (Christ Alpha 1-4 LSC, Germany) and kept at room temperature until use.

For measurement of gene expression during flower development (240 DAP), flowers of cultivar Q208 from the Sugar Research Australia Experiment Station at Meringa (Gordonvale, Queensland) were collected. Three flower stages were selected depending on the maturity of inflorescence. Normally in plants which showed staggered flowering, three stages were assigned: stage 1 (young flowers), stage 2 (moderately mature), and stage 3 (fully mature flower) (Figure S1). These flowers were submerged in RNAlater ${ }^{\mathrm{TM}}$ solution (Ambion, Austin, TX) and transported to Brisbane on the same day where they were stored at $4^{\circ} \mathrm{C}$. Samples were snap frozen in liquid nitrogen and powdered before extraction of RNA.

For tissue-specific gene expression of ShINH1, samples of stalk, leaf, flower, and root from mature plants (10 months old) were collected and prepared as described earlier.

\section{RNA Extraction}

Total RNA was isolated from tissue samples using an RNeasy Plant Mini Kit (including DNase digestion to remove remaining DNA) (QIAGEN, Chadstone, VIC, Australia) according to the manufacturer's directions. Briefly, $100 \mathrm{mg}$ of powdered tissue materials were suspended in $450 \mu \mathrm{l}$ RLT buffer (supplied with kit) and vortexed vigorously. Resulting tissue lysate was transferred to a spin column (Qiashredder) placed in $2 \mathrm{ml}$ collection tube and centrifuged at 13,000 rpm for $2 \mathrm{~min}$. To the supernatant, $500 \mu \mathrm{l}$ of ethanol (100\%) was added and mixed immediately by pipetting. Resulting cleared lysate was transferred to new spin column and centrifuged at 10,000 rpm for $30 \mathrm{~s}$. RNA bound spin column was washed twice with RW1 buffer (supplied with kit) and eluted with RNAse free water. All RNA samples were stored at $-80^{\circ} \mathrm{C}$ until required.

\section{Gene Isolation and Cloning}

To identify INVINH genes from sugarcane, Zea mays (NM_001157609) and Nicotiana tabacum (Y12806) INVINH sequences were used in BLASTn searches against sugarcane genome scaffolds available from the CSIRO sugarcane genome sequencing project using CLC Genomics Workbench (www. qiagenbioinformatics.com/products/clc-genomics-workbench/). We identified three homologs of the Z. mays INVINH gene but none of the tobacco INVINH gene (Figure S2). Primers were designed in different combinations to match the start and stop codon regions as well as $5^{\prime}$ and $3^{\prime}$ UTR region of the genomic sequences (Table 1). Oligonucleotides were custom synthesized by GeneWorks, Australia. Primer pairs were tested for their ability to amplify ShINH genes. Full-length sequences of two sugarcane INVINH genes were amplified (ShINH1 and ShINH2) from cDNA $(0.5 \mu \mathrm{g})$ synthesized from RNA isolated from internodal tissues, using a standard PCR amplification protocol with high-fidelity Platinum Taq Polymerase (Thermo Fisher Scientific, USA) (Figure S3). Amplified products were cloned into the pGEM-T Easy vector (Promega, Madison, WI, USA), then E. coli DH5 a cells transformed with recombinant plasmid were selected based on ampicillin resistance. Plasmids were isolated from confirmed colonies and restriction analysis performed using EcoRI to confirm the presence of a cloned gene (Figure S3). Recombinant plasmids (pGEM-T EasyShINH1/ShINH2) were sequenced using the dideoxy chain termination method (Sanger et al., 1977) using T7 and SP6 primers (Australian Genome Research Facility, The University of Queensland, Brisbane, Australia). 
TABLE 1 | Sequences of primers used for gene isolation, transcript expression assessment, vector construction for GFP localization, and recombinant protein expression.

\begin{tabular}{llll}
\hline Primer \# & Orientation & Use & Sequence $\left(\mathbf{5}^{\prime} \mathbf{- 3}^{\prime} \mathbf{)}\right.$ \\
\hline 1 & Forward & INH1 gene isolation & ATGAAGCTTCTGCAAGCTCTG \\
2 & Reverse & INH1 gene isolation & CTACAGCGCCTCCGTTACAGA \\
3 & Forward & INH2 gene isolation & ATGAAGCTAGTCTGCTCCGTG \\
4 & Reverse & INH2 gene isolation & TTAATCACTAATCTTTGGCCT \\
5 & Forward & INH1 qRTPCR & CGTCCAACGCTTCCGTCTTA \\
6 & Reverse & INH1 qRTPCR & GTCGGCCTGGAAGAACTTGA \\
7 & Forward & ADF qRTPCR & CTACTACTGTGGATTGTACGCCATTATAG \\
8 & Reverse & ADF qRTPCR & GGACCTTITTACACAGCAACAAAC \\
9 & Forward & INH1-GFP vector construct preparation & TATAACTAGTATGAAGCTTCTGCAAGCTCTG \\
10 & Reverse & INH1-GFP vector construct preparation & GCGGCCGCTTACTACAGCGCCTCCGTTACAGA \\
11 & Forward & PLIC INH1 expression vector construct preparation & TATATGGTACCGAGAACCTGTACTTCCAATC \\
& Reverse & PLIC INH1 expression vector construct preparation & ACATAGAGCTCTTACTACAGCGCCTCCGTTAC
\end{tabular}

\section{In Silico Characterization}

Nucleotide sequences of the ShINH1 and ShINH2 clones and their deduced amino acid sequences were used to identify the genes using BLAST programs at NCBI. Prediction of putative signal peptides was carried out using PrediSi (Hiller et al., 2004) and SignalP (Petersen et al., 2011) programs, while subcellular localization was predicted using PSORT (www. genscript.com/wolf-psort.html). Multiple sequence and pairwise alignments were performed using CLC Genomics Workbench. A phylogenetic tree was constructed with the neighbor-joining method using Mega 7.0 software (Kumar et al., 2016). Secondary structure prediction of ShINH1 was carried out using PSIPRED (http://bioinf.cs.ucl.ac.uk/psipred/) (Jones, 1999).

\section{GFP Localization}

To examine subcellular localization of ShINH1, wheat leaf and onion epidermal cells were transformed with UbilGFP-ShINH1 or UbilGFP gene constructs through particle bombardment using the method described by Xue (2002). Leaves of 1month-old wheat plants grown in a glasshouse under controlled conditions and fresh onion bulbs purchased locally were used. Newly expanded wheat leaves and onion epidermal tissue layers were freshly excised and placed in the center of a Petri dish on two layers of Whatman No. 1 filter paper saturated with a solution of $100 \mathrm{mM}$ sucrose, $5 \mathrm{mM}$ sodium phosphate, $\mathrm{pH}$ 7.0. The ZmUbil promoter-driven GFP constructs with or without ShINH1 fusion (Ubi1GFP-ShINH1 or UbilGFP) were constructed according to Xue (2002) and the UbiGFP without insert was used as a control (Figure 3A). Plasmid DNA was precipitated onto gold particles $(1 \mu \mathrm{m})$ and bombarded into wheat leaves and onion epidermal layers twice to increase the number of transformed cells in the tissues. The particle inflow gun was used at a pressure of $2,100 \mathrm{kPa}$ and a vacuum of $28 \mathrm{mmHg}$ (Patel et al., 2000). The bombarded tissues were kept at $20^{\circ} \mathrm{C}$ for $24 \mathrm{~h}$. Bombarded tissues were examined using fluorescence (Leica MZ16FA) and confocal (Zeiss Axiovert-200 with LSM 710 Meta Confocal Scanner) microscopy with excitation/emission of $480 / 510$ and $470 / 525 \mathrm{~nm}$, respectively.

\section{Expression Analysis Using Real-Time Quantitative PCR (RT-qPCR)}

For RT-qPCR analysis, cDNA was synthesized using a QIAGEN cDNA synthesis kit. Forward and reverse primers for ShINH1 gene were designed from the transcript sequence. A gene encoding actin depolymerising factor (ADF, GenBank CO373080) was used as the endogenous control (Casu et al., 2007). The expression level of ShINH1 was quantified from cDNA samples using a ViiATM 7 system (Applied Biosystems) and SYBR Green PCR Master Mix (Applied Biosystems) according to the manufacturer's instructions. Relative quantitation of mRNA levels was as described by Shaw et al. (2009).

\section{Production and Purification of Recombinant ShINH1}

The pLic-MBP expression vector was used to produce recombinant ShINH1 following the method described by Anangi et al. (2012) with some modifications. This vector encodes a MalE signal sequence for periplasmic export, a $\mathrm{His}_{6}$ affinity tag, a maltose binding protein (MBP) fusion tag to aid solubility, and a TEV protease recognition site directly preceding the ShINH1-coding region (Figure 5A). The plasmid encoding His $_{6}$-MBP-ShINH1 was transformed into E. coli strain BL21 for recombinant protein production. For protein production, the pre-inoculum was grown in LB medium overnight at $37^{\circ} \mathrm{C}$ with shaking $(180 \mathrm{rpm})$. The overnight cultures were diluted to $1 \mathrm{~L}$ with fresh $\mathrm{LB}$ medium and growth continued at $37^{\circ} \mathrm{C}$. Expression of ShINH1 was induced with $1 \mathrm{mM}$ IPTG when the $\mathrm{OD}_{600}$ reached 0.8 . Cultures were then grown overnight at $18^{\circ} \mathrm{C}$ with shaking at $180 \mathrm{rpm}$, after which bacteria were pelleted by centrifugation at $5,000 \mathrm{~g}$ for $20 \mathrm{~min}$ at $4^{\circ} \mathrm{C}$. Three approaches were initially tested for recovery of the soluble $\mathrm{His}_{6}$-MBPShINH1 fusion protein: (i) cells were lysed using a high-pressure cell disruptor (TS Series Benchtop model, Constant Systems Ltd, UK) in equilibration buffer ( $20 \mathrm{mM}$ Tris, $300 \mathrm{mM} \mathrm{NaCl}, 10 \%$ glycerol, $\mathrm{pH}$ 8.0); (ii) sonication (in the equilibration buffer); and (iii) extraction of the periplasmic fraction by osmotic shock (30 mM Tris, 20\% sucrose, $\mathrm{pH} 8.0$ and ice-cold water). 
The soluble His $_{6}$-MBP-ShINH1 fusion protein (buffered in $20 \mathrm{mM}$ Tris, $300 \mathrm{mM} \mathrm{NaCl}, 10 \%$ glycerol, $5 \mathrm{mM}$ imidazole, $\mathrm{pH}$ 8.0) was captured by passing the cell extract by gravity flow through a Ni-NTA Superflow resin (QIAGEN, Valencia, CA, USA). Unbound protein was eluted with equilibration buffer containing $15 \mathrm{mM}$ imidazole, then the fusion protein was then eluted with 25-500 mM imidazole. All fractions were examined for the presence of target protein using SDS-PAGE (Laemmli, 1970). Protein samples were pooled and concentrated using a $30-\mathrm{kDa}$ cutoff centrifugal filter (Amicon). The fusion partner ( His $\left._{6}-\mathrm{MBP}\right)$ was removed by adding reduced and oxidized glutathione (3.0 and $0.3 \mathrm{mM}$, respectively) to activate TEV protease. TEV protease was added (approximately $40 \mu \mathrm{g}$ per $\mathrm{mg}$ of $\mathrm{His}_{6}$-MBP-ShINH1), and the reaction was allowed to proceed at room temperature for $12 \mathrm{~h}$. The liberated ShINH1 was then separated from TEV protease, $\mathrm{His}_{6}-\mathrm{MBP}$, and uncleaved fusion protein using gel filtration chromatography (Sephacryl HiPrep S-200; GE Healthcare). The concentration of recombinant ShINH1 was determined from $\mathrm{A}_{280}$ absorbance measured using a NanoDrop spectrophotometer.

\section{Circular Dichroism (CD)}

Approximately $250 \mu \mathrm{g}$ of recombinant ShINH1 (from gel filtration chromatography) was dialyzed against $10 \mathrm{mM}$ Tris and $100 \mathrm{mM} \mathrm{NaF}$ overnight at $4^{\circ} \mathrm{C}$. The dialyzed ShINH1 was then concentrated using a $10-\mathrm{kDa}$ cut-off centrifugal filter (Amicon). CD spectra (190-250 $\mathrm{nm}$ range, $25^{\circ} \mathrm{C}$ ) were recorded from a $63.3 \mu \mathrm{M}$ sample of ShINH1 in a $0.1 \mathrm{~mm}$ cuvette using a Jasco J-180 spectropolarimeter.

\section{Invertase Activity Assay}

A commercial invertase assay kit employing yeast invertase (Cat.MAK118, Sigma Aldrich, USA) was used as per the manufacturer's protocol to examine the potency of recombinant ShINH1. Briefly, $40 \mu \mathrm{l}$ of reaction volume containing different concentrations of ShINH1 (100-500 nM) were pre-incubated in a 96-well plate with commercial acid invertase at $37^{\circ} \mathrm{C}$ for $30 \mathrm{~min}$. Glucose standards ( $40 \mu \mathrm{l}$ volume, $0-100 \mu \mathrm{M}$ glucose) were added to separate wells of the plate. The same volume of reaction buffer was used as the assay blank in separate wells. Substrate was added to each well ( $5 \mu \mathrm{l}$ of $20 \mathrm{mM}$ sucrose) followed by incubation for $20 \mathrm{~min}$ at room temperature. After incubation, the reaction mixture containing $95 \mu \mathrm{l}$ of reaction buffer, $1 \mu \mathrm{l}$ of enzyme mix and $1 \mu \mathrm{l}$ of dye reagent (all supplied with the kit) was prepared and $90 \mu \mathrm{l}$ of reaction mix was added to each of the blank, sample, and standard wells followed by incubation for $20 \mathrm{~min}$ at room temperature in darkness. After incubation, absorbance was recorded at $570 \mathrm{~nm}$ using a microplate reader and the amount of glucose liberated was calculated from the glucose standard curve. The specific activity of enzyme was calculated and expressed as $\mu$ moles of glucose formed per milligram of protein per minute. The concentration of ShINH1 required for $50 \%$ inhibition of enzyme activity $\left(\mathrm{IC}_{50}\right)$ was calculated by plotting nonlinear regression dose-response curve of Hill equation using GraphPad Prism 7.04 software.

\section{Statistical Analysis}

The analyses of gene expression and invertase enzyme activity were presented as means \pm SDs of three biological replicates. The data were analyzed with Duncan's multiple range test using Statistical Analysis system (SAS) software version 9.2 (www. iasri.res.in/sscnars/). $P<0.01$ was considered to be statistically significant.

\section{RESULTS}

\section{Identification and Sequence Characterization of ShINH1 and ShINH2}

Putative INVINH genes were identified in a sugarcane genome database assembled using short-read sequences from variety R570 (Aitken et al., 2016), covering over 97\% of transcribed unigenes. Although both maize (NM001157609) and tobacco (Y12805 \& Y12806) INVINH genes were used as query sequences, only the maize sequence aligned to sugarcane scaffolds, with three regions of homology identified (Figure S2). From these three genomic sequences, scaffold 413473 contained the longest alignment (640 bp); this sequence was designated ShINH2, and used directly for primer design and subsequent gene isolation. In contrast, scaffolds 2944351 and 762782 contained a distinct sequence that aligned to an uncharacterized sorghum genomic sequence of $531 \mathrm{bp}$, and this was designated ShINH1. Primers designed for the ORF regions amplified products of 531 and 576 bp for ShINH1 and ShINH2, respectively (Figure S3). ShINH1 and ShINH2 code for putative proteins of 177 and 192 amino acid residues with molecular masses of 18.2 and 20.0 $\mathrm{kDa}$, respectively (Figure S4). ShINH1 and ShINH2 are only $43.5 \%$ identical at the amino acid level, suggesting that they are not allelic forms but encode different INVINH proteins. The difference in protein characteristics between ShINH1 and ShINH2 are depicted in Table 2.

The deduced ShINH1 and ShINH2 protein sequences include putative signal peptides of 21 and 19 residues resulting in mature proteins of 15.8 and $17.0 \mathrm{kDa}$, respectively (Figure S5). Analysis of subcellular localization signals revealed that ShINH1 and ShINH2 are likely targeted to the extracellular space and vacuole, respectively (Figure S6). Alignment of the deduced sequences of ShINH1 and ShINH2 with other INVINH proteins from monocots and dicots revealed conservation of the four Cys residues that are a characteristic feature of all known plant INVINH proteins (Figure 1). Pairwise comparison of ShINH1 and ShINH2 with other plant INVINH proteins revealed that

TABLE 2 | Characteristics of ShINH1 and ShINH2 proteins.

\begin{tabular}{lcc}
\hline Feature & ShINH1 & ShINH2 \\
\hline Signal peptide (PREDISI) & $1-21 \mathrm{aa}$ & $1-19 \mathrm{aa}$ \\
Amino acids & $177 \mathrm{aa}$ & $192 \mathrm{aa}$ \\
Molecular weight & $18.17 \mathrm{kDa}$ & $19.97 \mathrm{kDa}$ \\
Isoelectric point & 8.91 & 4.88 \\
Localization signal (PSORT) & Apoplasmic & Vacuolar
\end{tabular}




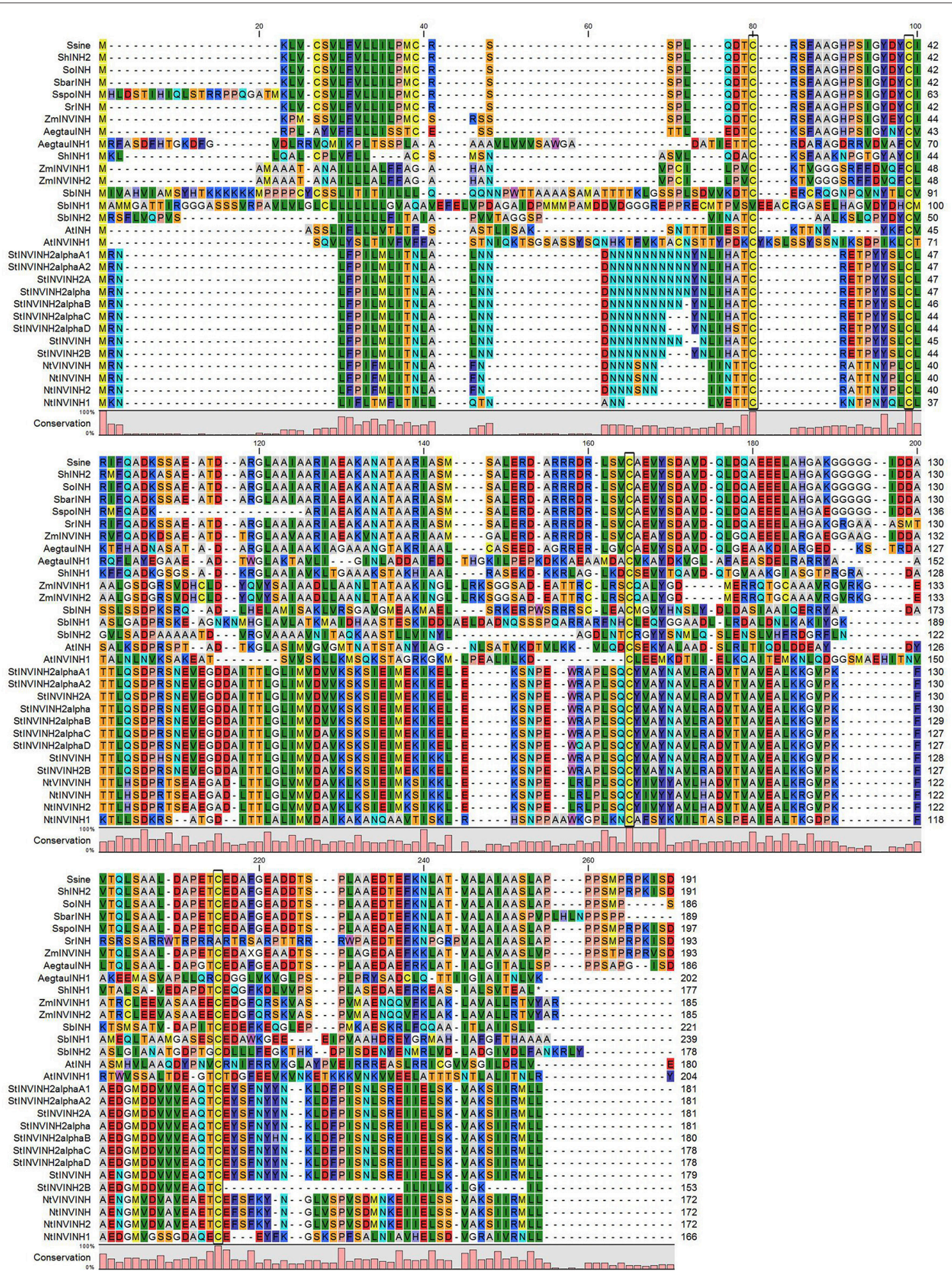

FIGURE 1 | Comparison of ShINH1 \& ShINH2 with plant invertase inhibitor-like proteins. Multiple sequence alignment of deduced amino acid sequences of plant invertase inhibitor (INVINH) proteins from S. sinense (SsinelNH, KP997206); Saccharum hybrid (ShINH2); S. officinarum (SolNH, KP997207); S. barberi (SbarlNH, KU057162); S. spontaneum (SspolNH, KP844455); S. robustum (SrINH, KP055631), Zea mays (ZmIN VINH, EU969422); Aegilops tautschi (AegtaulNH, XM_020320985; AegtaulNH1, XM_020311699); Saccharum hybrid, ShINH1); Sorghum bicolor (SbINH, XM_002453079; SbINH1, XM_002453080; SbINH2, XM_002452686), Zea mays (INVINH1, EU952678; INVINH2; EU960562); Arabidopsis thaliana (AtINH, Y12807; AtINVINH1, DQ056716); Solanum tuberosum

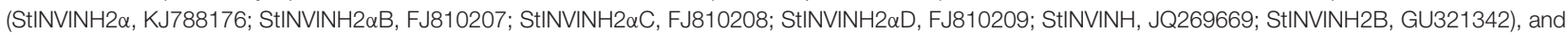
Nicotiana tobacum (NtVINVINH, AY145781; NtINVINH, AY594179; NtINVINH2, Y12805; NtINVINH1, Y12806). Conserved Cys residues are indicated by boxes. 
they cluster separately with plant INVINH1 and INVINH2 homologs, respectively. ShINH1 is most similar to monocot INVINH proteins, including Saccharum hybrid SoINVInh1 (97.2\%), Sorghum bicolor SbINHCWI/VAI (92.7\%), Z. mays ZmINHCWI/VAI (85.9\%), and Setaria indica SiPMEI (74.7\%), and has less than $24 \%$ identity with dicot INVINH proteins (Figure S7). ShINH2 is more analogous to wild Saccharum INVINH proteins with highest similarity of $99 \%$ to S. sinesse (SsineINH), 95.8\% to S. officinarum (SoINH), 92.3\% to S. barberi (SbarINH), 82.1\% to S. spontaneum (SspoINH), and $79.8 \%$ to S. robustum (SrINH), and in contrast has not more than $21 \%$ identity with dicot INVINH proteins.

To elucidate the phylogenetic relationship between ShINH1, ShINH2 and known plant INVINH proteins, their amino acid sequences were aligned and a neighbor-joining tree constructed (Figure 2). ShINH1 and ShINH2 clustered together with monocot INVINH proteins. ShINH1 is most closely related to SoInvInh1, an uncharacterized INVINH of Saccharum hybrid, and closely related to $Z$. mays (ZmINVINH1 and ZmINHCWI/VAI), Setaria indica (SiPMEI) and Sorghum bicolor (SbINHCWI/VAI) INVINH proteins. ShINH2 aligned more closely with Saccharum spp. INVINH proteins (Figure 2).

\section{Localization of ShINH1}

To examine the localization of ShINH1, we bombarded a GFP or ShINH1-GFP fusion construct into young wheat leaves and onion epidermal cells; in both constructs, gene expression is under control of the constitutive maize ubiquitin promoter (ZmUbi1; Figure 3A). In GFP controls, fluorescence was observed throughout the cell, including the nucleus (Figure 3B, panels I, III and V). In contrast, GFP-ShINH1 had a distinct localization pattern. No fluorescence signals were detected in the vacuole, and fluorescence in the nucleus and cytoplasm was reduced, whereas intense GFP fluorescence was detected at the periphery of wheat and onion cells (Figure 3B, panels II and VI), consistent with secretion of GFP-ShINH1 to the apoplast. The small amount of fluorescent signal in the cytoplasm might be due to the presence of transitory GFP-ShINH1 in the secretory pathway to the cell wall, (Figure 3B, panel II), which could be a feature of apoplastic proteins. Our data suggest that ShINH1 is predominantly localized to the apoplast and is a cell wall INVINH. However, confocal microscopic observation of wheat cells detected strong fluorescence signals in the cell wall and nucleus (Figure 3B, panel IV), in contrast to the results of fluorescence microscopic observation. Further detailed study is required to understand and validate the nature of ShINH1 localization in sugarcane.

\section{Temporal and Spatial Expression of ShINH1}

To examine tissue-specific and developmental expression of ShINH1, we extracted RNA from various sugarcane tissues, including leaf, root, flower, and stalk, and measured expression levels using qRT-PCR (Figure 4A). ShINH1 transcript levels were significantly lower in root and flower compared to leaf and stalk. Expression was lowest in roots as compared to leaf (2.1-fold higher), stalk (2.05-fold higher), and flowers (1.4fold higher) (Figure 4A). We also analyzed the expression of

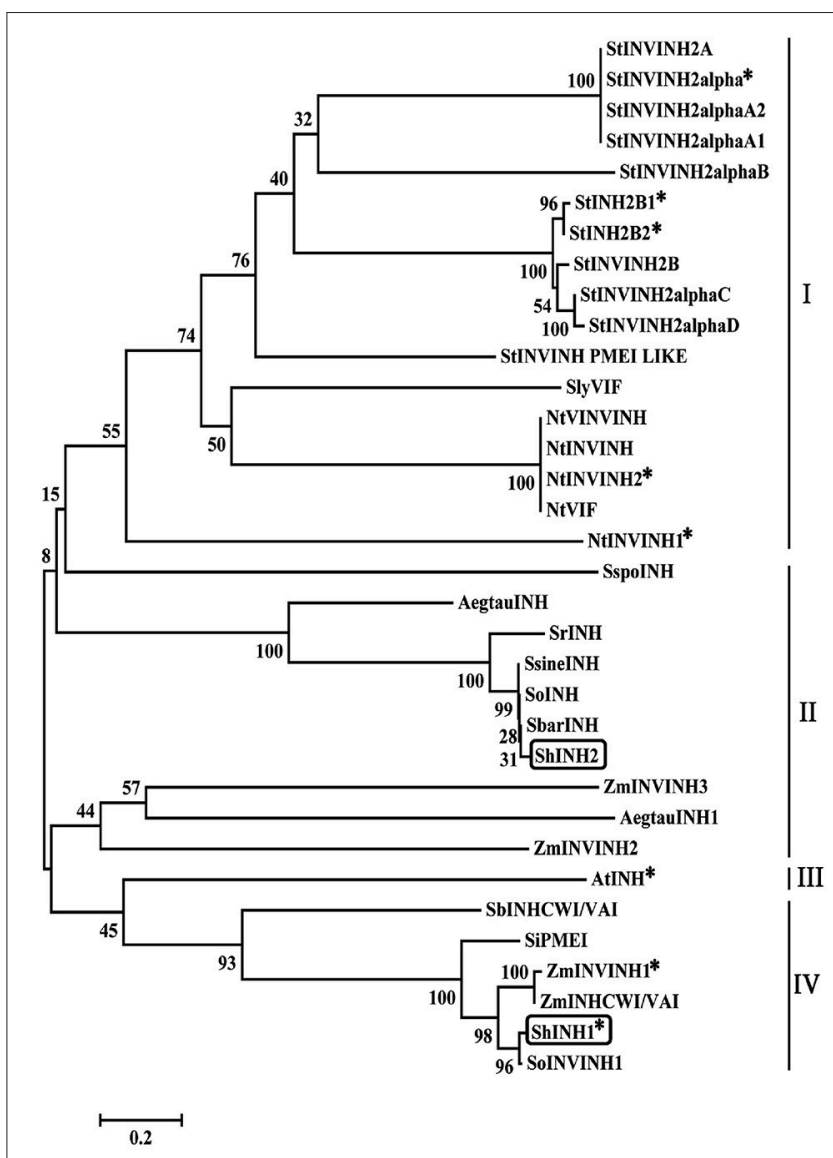

FIGURE 2 | Phylogenetic relationships of plant INVINH proteins. The phylogenetic tree was constructed by neighbor joining using aligned INVINH sequences analyzed by MEGA7.0. Asterisk ( $\left(^{\star}\right)$ indicates invertase inhibitors characterized experimentally. ShINH1 \& ShINH2 are shown in boxes. Dicot (I and III) and monocot (II and IV) INVINH proteins alignment are shown in lines. INVINH-like proteins from Solanum tuberosum (StINVINH2A, GU321341; StINVINH2 $\alpha$, KJ788176; StINVINH2 $\alpha A 2$, FJ810206; StINVINH2 $\alpha A 1$, FJ810205; StINVINH2aB, FJ810207; StINVINH2b1, ADZ54776; StINVINH2b2, GU980595; StINVINH2B, GU321342; StINVINH2 $\alpha \mathrm{C}$, FJ810208; StINVINH2aD, FJ810209; StINVINH PMEI LIKE,); Solanum lycopersicum, (KC007445); Nicotiana tobacum (NtVINVINH, AY145781; NtINVINH, AY594179; NtINVINH2, Y12805; NtVIF, AAN60076; NtINVINH1, Y12806); S. spontaneum (SspolNH, KP844455); Aegilops tautschi (AegtaulNH, XM_020320985); S. robustum (SrINH, KP055631); S. sinense (SsinelNH, KP997206); S. officinarum (SolNH, KP997207); S. barberi (SbarINH, KU057162); Saccharum hybrid (ShINH2, MG457817); Zea mays (ZmINVINH3, CAC69343); A. tautschi (AegtaulNH1, XM_020311699); Z. mays (ZmINVINH2, CAC69336); Arabidopsis thaliana (AtINH, Y12807); Sorghum bicolor (SbINHCWI/NAI, XM_002446958.2); Setaria indica (SiPMEI, XM_004978185.1); Z. mays (ZmINVINH1; ZmINHCWINAI, XM_008670754.2) and Saccharum hybrid (ShINH1, MG457818; SolNVINH1, KF575171;). A total of 1,000 bootstrapping runs were performed and \% reliability is labeled next to each branch. ShINH1 and ShINH2 clustered within the Saccharum spp. and were closely related to monocot INVINH proteins.

ShINH1 at different stages of stalk development by quantifying transcript levels in internodal tissues I4, I8 and I13. ShINH1 expression was significantly higher (1.94- and 2.69-fold) in young immature internodes (I4) compared with moderately (I8) and fully (I13) mature internodes (Figure 4B). The decrease 
A

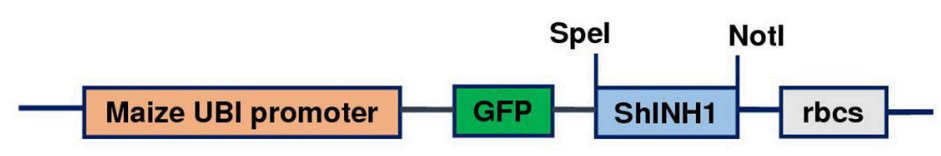

B

B Ubi1GFP
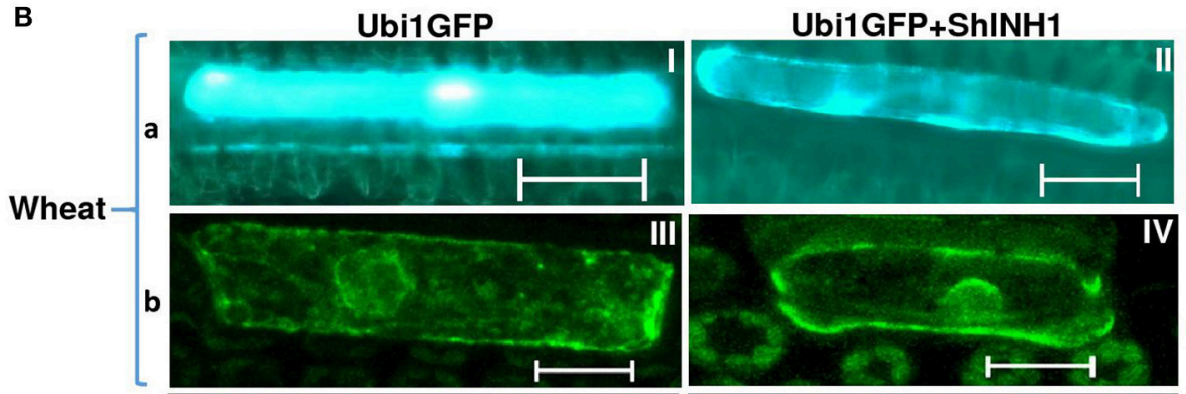

Onion
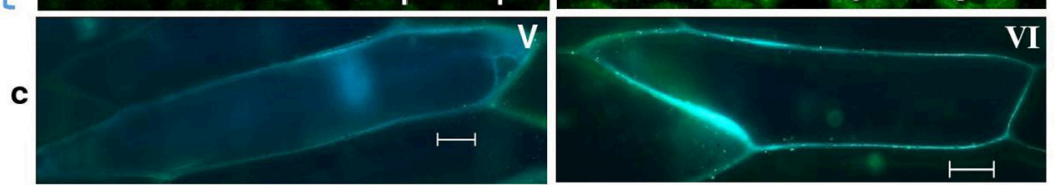

FIGURE 3 | Subcellular localization of ShINH1 protein. (A) GFP-ShINH1 construct under control of the maize UBi1 promoter. (B) Transient expression of UBi1GFP (control) and Ubi1GFP-ShINH1. Particle bombardment into wheat leaves and onion epidermal cells was performed and cells visualized using fluorescence and confocal microscopy $36 \mathrm{~h}$ after incubation at room temperature. (a and b) fluorescent and confocal images of wheat leaf cells. (c) Florescent image of onion epidermal cells. (I, III, and V: GFP controls) GFP accumulation in cytoplasm, nucleus and cell wall. (IV) Accumulation of GFP-ShINH1 in the cell wall, nucleus and cytoplasmic strands in wheat leaf cells. (II and VI) Enhanced fluorescence at the periphery of the cell indicates that GFP-ShINH1 localizes to the cell wall/apoplasmic region.

in ShINH1 expression during stalk maturation may suggest a regulatory role for this INVINH in sucrose accumulation during stalk development.

We also studied ShINH1 expression in flowers at different stages of maturity. Expression of ShINH1 in young flowers (Stage 1) was 1.5- and 1.2-fold higher, respectively, than in moderately mature (Stage 2) and fully mature (Stage 3) flowers (Figure 4C). Although there are significant differences in ShINH1 expression between flowering stages, there was no clear correlation between gene expression level and flower maturity.

\section{Characterization of Recombinant ShINH1}

To determine whether ShINH1 functions as an invertase inhibitor in vitro, we expressed recombinant ShINH1 in E. coli and purified the recombinant protein to homogeneity using a combination of nickel affinity and gel filtration chromatography (Figures 5B, C, 6A). The E. coli periplasmic expression system yielded $\sim 1.0 \mathrm{mg} / \mathrm{L}$ of soluble ShINH1. The CD spectrum of recombinant ShINH1 contained minima at 222 and $209 \mathrm{~nm}$, which are diagnostic of $\alpha$-helical secondary structure (Figure 6B). The CD spectrum is consistent with the secondary structure predicted by PSIPRED (Figure S8) and the structurally well-characterized tobacco invertase inhibitor (Hothorn et al., 2010).

Recombinant ShINH1 was found to be a potent inhibitor of acid invertase, with the concentration-response data yielding an $\mathrm{IC}_{50}$ of $22.5 \mathrm{nM}$ (Figure 7 ). This potent inhibitory activity is consistent with ShINH1 playing a role in post-translational regulation of sugarcane invertases.

\section{DISCUSSION}

In the present study, we identified two INVINH gene homologs (ShINH1 and ShINH2) in sugarcane and, for the first time, experimentally demonstrated that sugarcane INVINH proteins are potent invertase inhibitors.

INVINH genes have been discovered in numerous plant species (Greiner et al., 1999; Bate et al., 2004; Brummell et al., 2011; Qin et al., 2016). Amongst the Saccharum spp., six uncharacterized INVINH genes, in addition to ShINH1 and ShINH2, have been reported (Figure 1 and Figure S7). The features of the ShINH1 and ShINH2 proteins clearly place them within the family of invertase inhibitors. Both proteins possess four cysteine residues, predicted to form two disulfide bridges, a conserved feature across all plant INVINH proteins (Figure 1; Bate et al., 2004; Rausch and Greiner, 2004; Brummell et al., 2011), and CD analysis of ShINH1 revealed a high proportion of $\alpha$-helical secondary structure, consistent with the tobacco homolog (Hothorn et al., 2004; Rausch and Greiner, 2004). Phylogenetic analysis revealed that ShINH1 and ShINH2 are most closely related to other monocot INVINH sequences (Figure 2).

Many plant species appear to contain multiple INVINH isoforms that are directed to separate subcellular compartments by protein targeting elements. For example, in tobacco, NtINH is vacuolar while the related NtINH1 is located in the cell wall (Weil et al., 1994; Greiner et al., 1998). Similarly, in potato, INH1 is localized to the cytoplasm and cell wall, whereas INH2 is found in the cytoplasm and vacuole (Brummell et al., 2011). The putative signal peptides in ShINH1 and ShINH2 are predicted 

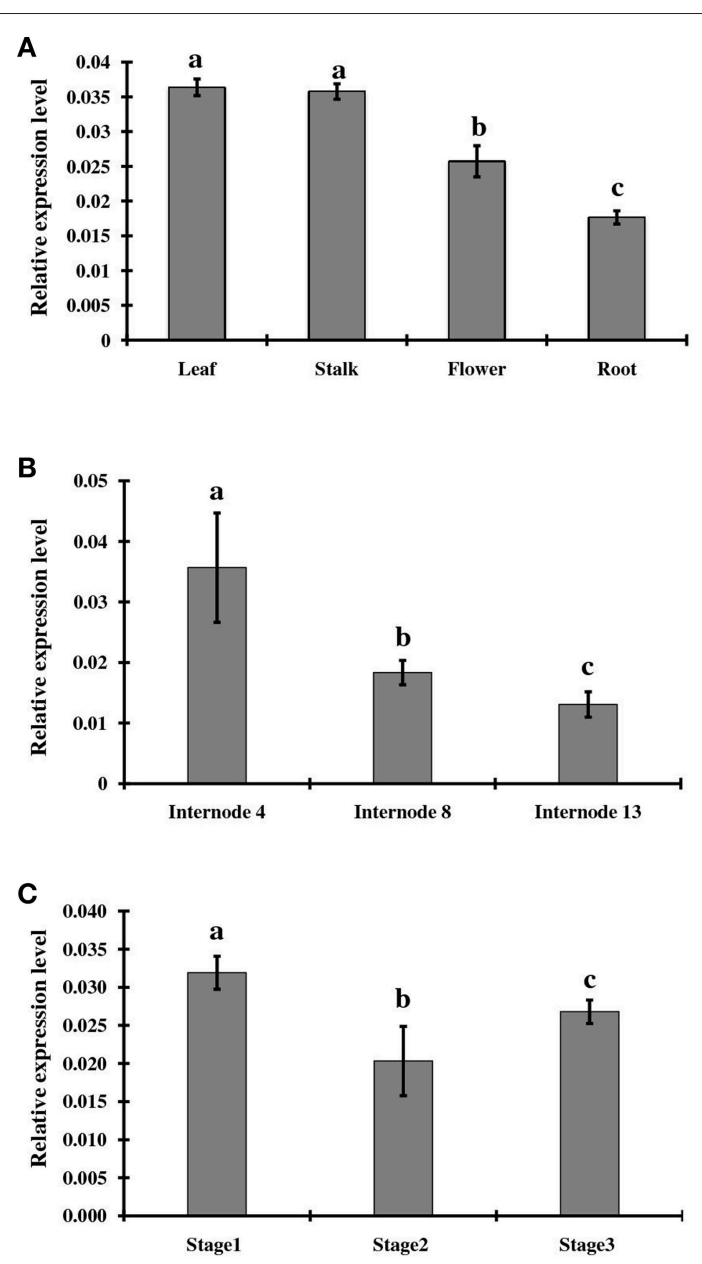

FIGURE 4 | Relative expression levels of ShINH1 in sugarcane. (A) Tissue specific expression of ShINH1 in leaf, stalk, flower, and root tissues obtained from mature sugarcane plants. Significantly increased expression of ShINH1 was observed in leaf and stalk as compared to flower and root. (B) Developmental expression of ShINH1 in sugarcane stem during sucrose accumulation. Analysis of internodes 14 (young), 18 (moderately mature) and 113 (fully mature) from pooled internodal tissues revealed significant expression of ShINH1 in 14 compared to 18 and I13. (C) Relative expression levels of ShINH1 during flower development. Flowers from stage 1 (young flowers), stage 2 (moderately mature) and stage 3 (fully mature flowers) were used. Values are mean $\pm S D$ of 3 biological replicates. Lower case letters with same or different alphabets indicate statistically non-significant and significant respectively (Duncan's multiple range test; $P<0.01$ ).

to direct the mature proteins to the endoplasmic reticulum for ultimate secretion to the apoplast and vacuole, respectively (Figures S5, S6). This is consistent with our observation that ShINH1-GFP fusion protein was detected primarily in the cell wall in both wheat leaves and onion epidermal cells (Figure 3), although this needs further investigation, as some cellular signal was also observed. Although localization of ShINH2 was not experimentally examined, we predict it is localized to the vacuole.

In general, tissue specific expression of INVINH genes varies among plant species depending on the source-sink dynamics. As INVINH proteins are integral modulators of invertase, they are frequently expressed in similar developmental and anatomical patterns to invertase enzymes. For example, it has been proposed that kernel-specific expression of ZmINH1 has a regulatory role in endosperm and embryo development in maize, helping to maintain hexose/sucrose ratios by controlling the activity of apoplasmic invertase (Bate et al., 2004). In potato, where invertase and its inhibitors have been extensively characterized, starch is the major carbohydrate accumulated in the tubers, which act as sinks for photosynthate. During tuber growth, reduced expression of potato INVINH genes favors starch accumulation over sucrose because the invertase is an essential step in conversion of sucrose to starch precursors. However, cold-induced sweetening of potato tubers may occur through the activity of invertase during post-harvest and this was successfully reduced by high expression of StINH mRNA in tubers (Greiner et al., 1999; Brummell et al., 2011).

In sugarcane, ShINH1 is more strongly expressed in leaf and stalk than root and flowers (Figure 4A), although some expression was seen throughout the plant. The current study also revealed that ShINH1 expression is developmentally regulated during internodal maturation, with higher levels in young internodes (I4) compared to moderately mature (I8) and fully mature internode (I13) (Figure 4B). It has been reported that expression of invertase enzymes is higher in young sugarcane tissues where rapid sucrose hydrolysis occurs to provide substrates for cell wall biosynthesis and other reactions (Zhu et al., 1997; Chandra et al., 2015). It is likely that higher expression of ShINH1 in young internodes is part of a post-translational control mechanism involving feedback regulation of sucrose biosynthesis and degradation where invertase enzymes exist. Similarly in the storage tissues of mature internodes, ShINH1 may add an additional mechanism to control futile cycling between sucrose and hexoses to regulate sucrose accumulation in the stalk.

We examined expression of ShINH1 in inflorescences to elucidate its role in carbon partitioning during development of reproductive structures, based on the role of the INH1 homolog in other species. It was previously shown that expression of StINH1 in potato (Brummell et al., 2011), NtINH1 in tobacco (Greiner et al., 1998) and SolyCIF in tomato (Reca et al., 2008) is highest in flowers. In tomato, a vacuolar-targeted INVINH plays an important role in sucrose-mediated fruit ripening by regulating the activity of a ripening inhibitor (Qin et al., 2016). Although ShINH1 was expressed in sugarcane flowers at three developmental stages, including early seed development (Figure 4C), this was not the tissue with the highest expression level and there was no clear correlation with maturation. This may reflect the lack of fruit structures in monocot seeds together with the small size of sugarcane seeds and their relatively low starch content (Siqueira et al., 2015).

Considering the complexity of sucrose metabolism in sugarcane due to its multiple genes and intricate source-sink dynamics, it will be essential to understand the molecular regulation of sucrose accumulation in order to improve yields (Rae et al., 2005; Chandra et al., 2011; Suresha et al., 2017). There are still many unanswered questions about the capacity of sugarcane sink tissue to store sucrose and its requirement and 

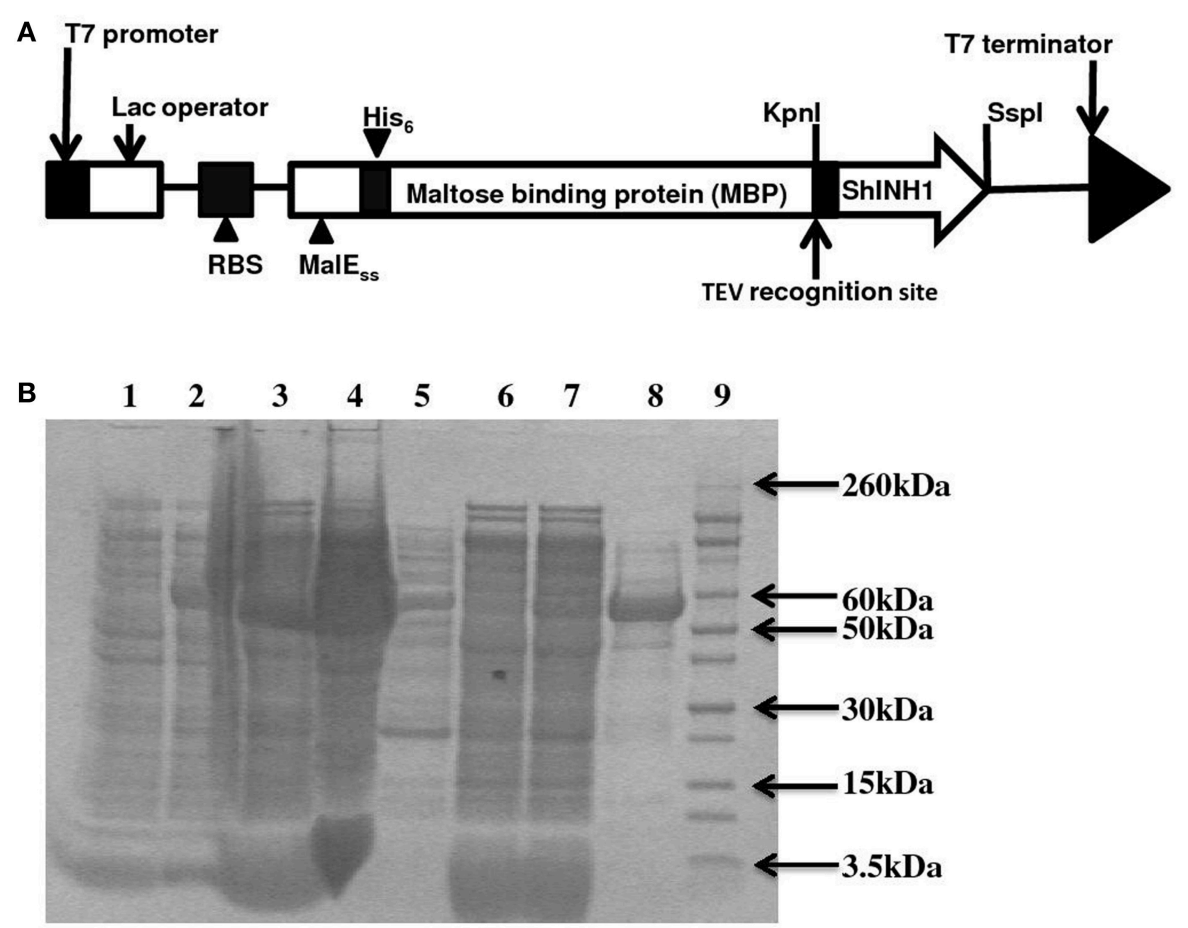

\section{101112131415161718192021222324}

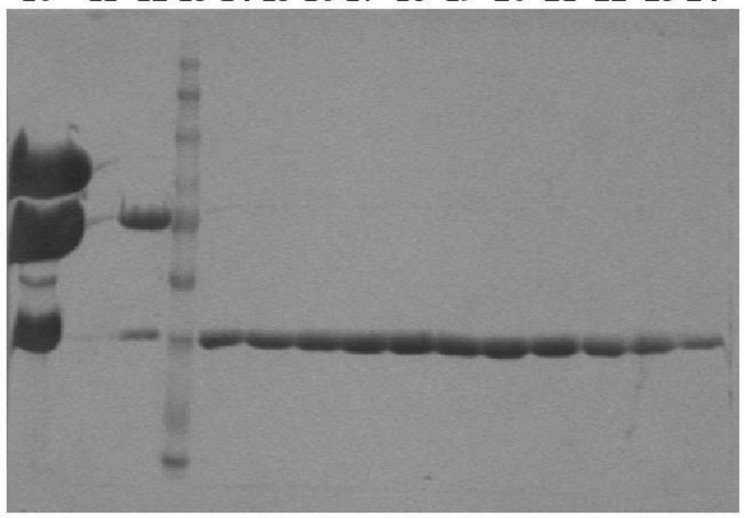

FIGURE 5 | Recombinant ShINH1 expression in E. coli. (A) Schematic of construct encoding a His 6 -MBP: ShINH1 fusion protein for production of recombinant ShINH1 in E. coli. SDS-PAGE gels showing expression and purification of recombinant ShINH1: (B) Production and NiNTA purification of recombinant ShINH1 and (C) TEV cleavage and purification of recombinant ShINH1 through gel filtration column chromatography. Lane1: Pre induction sample; Lane2: IPTG induction sample; Lane3: Insoluble fraction; Lane4: Soluble fraction; Lane5: flow through; Lane6: $10 \mathrm{mM}$ imidazole wash; Lane7: $30 \mathrm{mM}$ Imidazole wash; Lane8: $300 \mathrm{mM}$ imidazole wash; Lane9: Molecular size marker (Novex Sharp pre-stained protein ladder; Thermofisher Scientific, USA); Lane10: TEV protease treated sample; Lane12: Fraction containing cleaved His6-MBP and ShINH1; Lane13: Molecular size marker; Lanes14-24: Purified ShINH1 Samples.

mechanism of partitioning for growth and development of the plant. Previous approaches to understanding sink strength and transport kinetics have used transcriptomic analyses to identify key genes and pathways (Casu et al., 2005; Watt et al., 2005). Post-translational regulation has received less attention, partly because it has been difficult to address in this non-model system lacking the resources of complete genome and metabolome profiles. The recent availability of sugarcane genome information has now allowed us to identify a regulator of enzyme activity which could open new avenues to manipulation of sucrose accumulation.

Ectopic expression of INVINH proteins from tobacco (Greiner et al., 1999) and potato (Brummell et al., 2011) in transgenic potato tubers has been used to control invertase activity. A similar approach may be effective in sugarcane, assisted by the availability of well-established transformation systems and protocols for subcellular targeting of proteins for in planta expression (Jackson et al., 2007, 2010; Rae et al., 2009, 

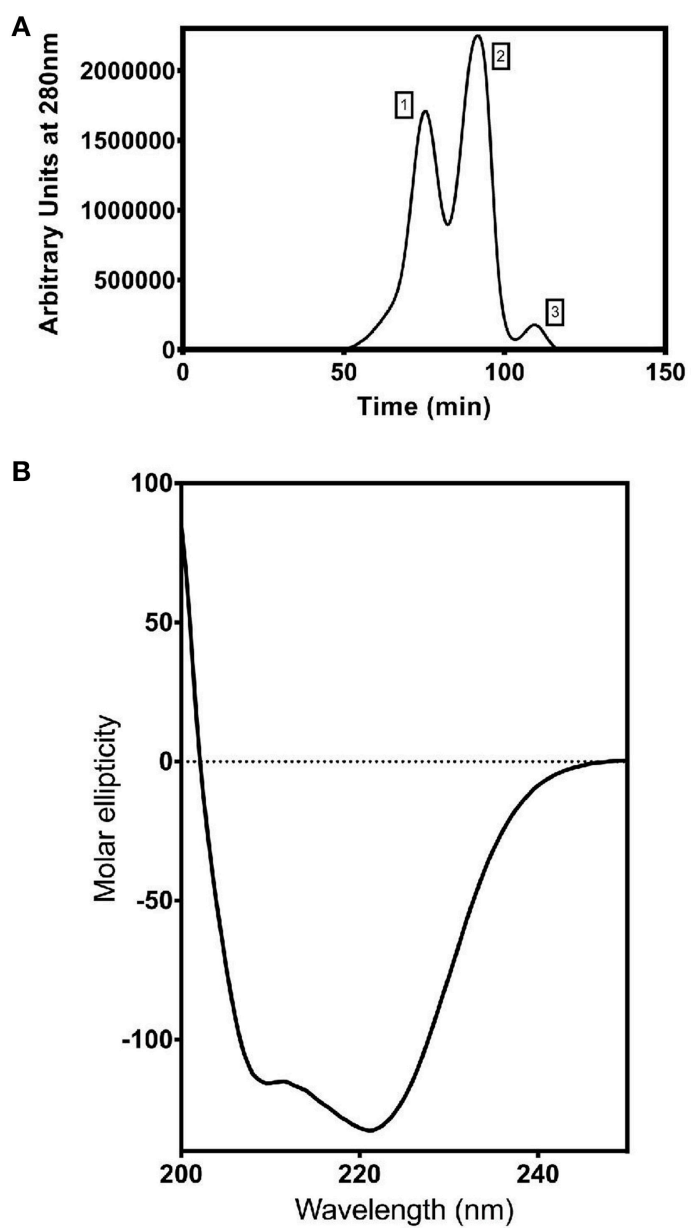

FIGURE 6 | Purification and characterization of recombinant ShINH1. (A) Fractionation of recombinant ShINH1 using gel filtration chromatography. A HiTrap S-200 prepacked gel filtration column was used to separate TEV cleaved recombinant ShINH1 (peak 3) from uncleaved (His $6-\mathrm{MBP}$ : ShINH1 as peak 1) and $\mathrm{His}_{6}-\mathrm{MBP}$ (peak 2) fractions shown in the chromatogram. (B) Circular dichroism (CD) spectrum of recombinant ShINH1 obtained at $25^{\circ} \mathrm{C}$. The CD spectrum contains minima at 222 and $209 \mathrm{~nm}$, which are diagnostic of $\alpha$-helical secondary structure.

2010; Palaniswamy et al., 2016). Furthermore, by using inducible expression, it may be possible to increase INVINH expression specifically at the time of harvest so as to reduce post-harvest loss of sucrose. Chandra et al. (2014) reported that acid invertase enzymes are involved in the degradation of sucrose during cane maturity and post-harvest. In addition to endogenous invertases, micro-organisms that colonize and grow in cut sugarcane stalks also produce invertases that further contribute to sucrose loss. Application of anti-microbial formulations at the time of harvest slows the rate of sucrose breakdown but losses are still substantial (Singh et al., 2008). It is likely that plant invertase inhibitors would be effective against both plant and microbial invertases. The advantage of functional specificity of ShINH1 established in the present work against soluble acid invertase provides a new avenue that may pave the way for controlling the activity of invertase enzymes during growth

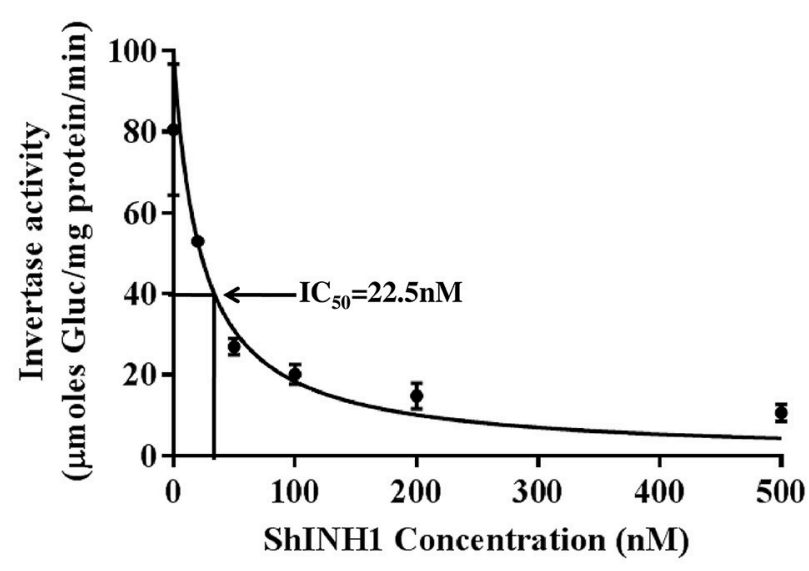

FIGURE 7 | Recombinant ShINH1 inhibits invertase in vitro. The activity of commercial acid invertase (Sigma) was measured after pre-incubation with 0-500 nM recombinant ShINH1 and the concentration of ShINH1 that yields $50 \%$ inhibition calculated as the $\mathrm{IC}_{50}$ using GraphPad Prism 7.04 software. Data are presented as mean $\pm S D$ of three reactions. Statistical significance was compared between the different ShINH1 concentrations (Duncan's multiple range test; $P<0.01$ ).

and prevent sucrose losses during the post-harvest period. In addition to controlling sucrose accumulation, it has been shown that invertases play important roles in regulation of various physiological processes like seed development and maturity, leaf senescence, drought and cold stresses and defense pathways (Jin et al., 2009; Bonfig et al., 2010; Ni, 2012; Chen et al., 2016; Tang et al., 2017; Xu et al., 2017; Zuma et al., 2018). Manipulation of invertases through specific INVINHs may lead to physiological and biochemical changes in plants through control of metabolic flux and source-sink balance of sugars (Roitsch and Gonzalez, 2004; Tauzin and Giardina, 2014). Therefore, INVINHs are valuable candidates for post-translational regulation of invertases through which many traits of interest can be modified to enhance crop yield.

\section{CONCLUSIONS}

In this study, we identified two sugarcane invertase inhibitors (ShINH1 and ShINH2) and demonstrated the function of ShINH1 against an invertase enzyme. This is the first report to ascertain the functional identity of a sugarcane invertase inhibitor. We also provided the evidence for a role for ShINH1 in regulation of sucrose accumulation by studying its temporal and spatial expression in sugarcane. The functional significance of sugarcane invertase inhibitors established in this study offers new opportunities to enhance the yield of sucrose and sugar recovery by regulating the activity of invertase enzymes and preventing pre-and post-harvest sucrose deterioration, although careful attention would be required to monitor changes in the growth and development of transgenic plants. Nevertheless, precise targeting of vacuolar invertases by using stalk specific wound/harvest inducible promoters has the potential to have more impact on sucrose yield which is yet to be accomplished in sugarcane. 


\section{ACCESSION NUMBERS}

The nucleotide sequences for ShINH1 and ShINH2 reported in this manuscript have been submitted to GenBank with accession numbers MG457817 and MG457818, respectively.

\section{AUTHOR CONTRIBUTIONS}

SS: conceived, designed, and performed the experiments, analyzed data, and drafted the manuscript; RA: contributed to protein expression, purification, enzyme assays, $\mathrm{CD}$ analyses, and manuscript preparation; SK: contributed to gene expression analysis and GFP localization experiments; DG: contributed to generation of sugarcane tissue samples and genes cloning; GK: advised on protein expression and contributed to manuscript writing; AR: contributed to collection of flower samples, manuscript preparation and editing, and supervised all experiments.

\section{FUNDING}

This work was supported by the Commonwealth Scientific and Industrial Research Organization (CSIRO), the Department of Biotechnology, Government of India (Indo-Australian Career Boosting Gold Fellowship to SGS), and the Australian National Health \& Medical Research Council (Principal Research Fellowship APP1044414 to GFK).

\section{ACKNOWLEDGMENTS}

We are grateful to Dr. Rosanne Casu and Dr. Gangping Xue (CSIRO) for constructive suggestions, Paul Berkman (CSIRO) for help in retrieval of INVINH sequences from the sugarcane genome database, John Griffin (Institute for Molecular Bioscience) for assistance with confocal microscopy, the Meringa Sugar Research Australia Experiment Station (Gordonvale, Queensland) for assistance with flowering sample collection, Jai Perroux for technical assistance, and Terry Grant for maintenance of the controlled environment facility for growing sugarcane plants.

\section{SUPPLEMENTARY MATERIAL}

The Supplementary Material for this article can be found online at: https://www.frontiersin.org/articles/10.3389/fpls.2018. 00598/full\#supplementary-material

Figure S1 | Sugarcane flowers of different maturity stages used for ShINH1 expression analysis. Flowers were collected from field-grown plants based on level of maturity. Stage 1 (young flowers), stage2 (moderately mature), and stage3 (fully mature) in three replicates are shown. Both top and bottom parts of each were used for expression analysis of ShINH1.
Figure S2 I Zea mays (ZmINH; NM_001157609) and Nicotiana tabacum (NtINH; Y12806) INVINH sequences were used to search for potential sugarcane INVINH sequences via a BlastN search against the sugarcane genome database. Three hits were obtained using the $\mathrm{ZmINH}$ sequence, but none were obtained using the NtINH sequence.

Figure S3 | Isolation of sugarcane INVINH genes (ShINH1 and ShINH2). PCR amplification of stem cDNA using gene-specific primers and EcoRI-digested pGEM-T-ShINH1/INH2 recombinant plasmids are shown using1\%agarose gels. Lane M: 1 kb DNA ladder; Lane 1:ShINH1 PCR-amplified product; Lanes 2-7: EcoRI-restricted ShINH1 recombinant plasmids; Lanes 9-10: ShINH2 PCR amplified product; Lanes 11-16: EcoRI-restricted ShINH2 recombinant plasmids.

Figure S4 | Nucleotide and deduced amino acid sequences of the ShINH1 and ShINH2genes. (A) Alignment of nucleotide sequences consisting of 531 and 576 bp ORFs with start codon ATG and stop codon TAG and TAA respectively. (B) Alignment of deduced amino acid sequences of ShINH1 and ShINH2 genes consisting of 177 and 192 amino acid residues respectively. Putative signal peptides are marked with a box in both the nucleotide and amino acid sequences.

Figure S5 | Prediction of signal peptide in the ShINH1 \& ShINH2 proteins. The deduced amino acid sequences of ShINH1 and ShINH2 were analyzed for signal peptide sequences using Predisi (www.predisi.de). A signal peptide was identified with high confidence (Predisi score of 0.87 on a 0-1 scoring scale) at (A) residues 1-21 of ShINH1 and (B) residues 1-19 of ShINH2.

Figure S6 | Prediction of subcellular localization of ShINH1 \& ShINH2. Analysis of the deduced amino acid sequences of ShINH1 and ShINH2 proteins were analyzed for subcellular localization signals using PSORT (https://wolfpsort.hgc.jp) revealed that (A) ShINH1 is likely targeted to an extracellular location (i.e., cellwall/apoplasmic space; indicated in green), whereas (B) ShINH2 is predicted to be localized in the vacuolar lumen (indicated in red). Names of identical protein hits, localization, distance score, \% identity and localization prediction are shown with lower distance scores indicating higher prediction values. Localization sites are indicated as extr, extracellular; chlo, chloroplast; nucl, nucleus; mito, mitochondria; cyto, cytoplasm; vacu, vacuole.

Figure S7 | Pairwise comparison of deduced amino acid sequences of ShINH1 \& ShINH2 with plant INVINH-like proteins from S. sinense (SsinelNH, KP997206); Saccharum hybrid (ShINH2); S. officinarum (SolNH, KP997207); S. barberi (SbarlNH, KU057162); S. spontaneum (SspolNH, KP844455); S. robustum (SrINH, KP055631), Zea mays (ZmIN VINH, EU969422); Aegilops tautschi (AegtaulNH, XM_020320985; AegtaulNH1, XM_020311699); Saccharum hybrid (SolNVInh1, KF575171; ShINH1); Sorghum bicolor (SbINH, XM_002453079; SbINH1, XM_002453080; SbINH2, XM_002452686 SbINHCWINAI, XM_002446958.2), Zea mays (INVINH1, EU952678; INVINH2; EU960562; ZmINHCWINAI, XM_008670754.2); Setaria indica (SiPMEl, XM_004978185.1); Arabidopsis thaliana (AtINH, Y12807; AtINVINH1, DQ056716); Solanum tuberosum (StINVINH2 $\alpha$, StINVINH2 $\alpha$, KJ788176; StINVINH2 $\alpha B$, FJ810207; StINVINH2 $\alpha$ C, FJ810208; StINVINH2 $\alpha$ D, FJ810209; StINVINH, JQ269669; StINVINH2B, GU321342), and Nicotiana tabacum (NtVINVINH, AY145781; NtINVINH, AY594179; NtINVINH2, Y12805; NtINVINH1, Y12806). Values indicate $\%$ similarity of INVINH proteins against each other. Colored boxes with numbers indicate degree of similarity: Light to dark red indicates moderate to high similarity whereas light to dark blue indicates moderately low to least similarity.

Figure S8 | Prediction of secondary structure of ShINH1 and ShINH2 proteins. Deduced amino acid sequences of ShINH1 and ShINH2 proteins were analyzed for secondary structure using PSIPRED tool (http://bioinf.cs.ucl.ac.uk/psipred/). Both (A) ShINH1 and (B) ShINH2 were predicted to form predominantly $\alpha$-helical secondary structure. Helical structure is indicated by the letter " $\mathrm{H}$ " and pink cylinders whereas, coil regions are indicated by the letter "C" and horizontal lines. Confidence of prediction is shown by the blue colored bars.

\section{REFERENCES}

Aitken, K., Berkman, P., and Rae, A. (2016). The first sugarcane genome assembly; how can we use it? Proc. Aust. Soc. Sugar Cane Technol. 38, 193-199.

Anangi, R., Rash, L. D., Mobli, M., and King, G. F. (2012). Functional expression in Escherichia coli of the disulfide-rich sea anemone peptide APETx2, a potent blocker of acid-sensing ion channel 3. Mar. Drugs 10, 1605-1618. doi: $10.3390 / \mathrm{md} 10071605$ 
Bate, N. J., Niu, X., Wang, Y., Reimann, K. S., and Helantjaris, T. G. (2004). An invertase inhibitor from maize localizes to the embryo surrounding region during early kernel development. Plant Physiol. 134, 246-254. doi: 10.1104/pp.103.027466

Bieleski, R. L. (1960). The physiology of sugarcane. III. Characteristics of sugar uptake in slices of mature and immature storage tissue. Aust. J. Biol. Sci. 13, 203-220. doi: 10.1071/BI9600203

Bonfig, K. B., Gabler, A., Simon, U. K., Luschin-Ebengreuth, N., Hatz, M., Berger, S., et al. (2010). Post-translational derepression of invertase activity in source leaves via down-regulation of invertase inhibitor expression is part of the plant defense response. Mol. Plant 3, 1037-1048. doi: 10.1093/mp/ssq053

Botha, F. C., Sawyer, B. J. B., and Birch, R. G. (2001). Sucrose metabolism in the culm of transgenic sugarcane with reduced soluble acid invertase activity. Proc. Int. Soc. Sugar Cane Technol. 24, 588-591.

Brummell, D. A., Chen, R. K., Harris, J. C., Zhang, H., Hamiaux, C., Kralicek, A. V., et al. (2011). Induction of vacuolar invertase inhibitor mRNA in potato tubers contributes to cold-induced sweetening resistance and includes spliced hybrid mRNA variants. J. Exp. Bot. 62, 3519-3534. doi: 10.1093/jxb/err043

Bussis, D., Heineke, D., Sonnewald, U., Willmitzer, L., Raschke, K., and Heldt, H. W. (1997). Solute accumulation and decreased photosynthesis in leaves of potato plants expressing yeast-derived invertase either in the apoplast, vacuole or cytosol. Planta 206, 126-136. doi: 10.1007/s004250050111

Casu, R. E., Jarmey, J. M., Bonnett, G. D., and Manners, J. M. (2007). Identification of transcripts associated with cell wall metabolism and development in the stem of sugarcane by Affymetrix gene chip sugarcane genome array expression profiling. Funct. Integr. Genomics 7, 153-167. doi: 10.1007/s10142-006-0038-Z

Casu, R. E., Manners, J. M., Bonnet, G. D., Jackson, P. A., McIntyre, C. L., Dunne, R., et al. (2005). Genomics approaches for the identification of genes determining important traits in sugarcane. Field Crop Res. 92, 137-147. doi: 10.1016/j.fcr.2005.01.029

Chandra, A., Jain, R., Rai, R. K., and Solomon, S. (2011). Revisiting the source-sink paradigm in sugarcane. Curr. Sci.100, 978-980.

Chandra, A., Jain, R., and Solomon, S. (2012). Complexities of invertases controlling sucrose accumulation and retention in sugarcane. Curr. Sci.102, $857-866$.

Chandra, A., Roopendra, K., Singh, P., Jain, R., Prajapati, C. P., and Solomon, S. (2014). Time-course expression of soluble acid invertase (SAI) gene mirroring post-harvest cane quality deterioration: effective treatments cause reduction of SAI gene expression. Curr. Sci.107, 184-186.

Chandra, A., Verma, P. K., Islam, M. N., Grisham, M. P., Jain, R., Sharma, A., et al. (2015). Expression analysis of genes associated with sucrose accumulation in sugarcane (Saccharumspp. hybrids) varieties differing in content and time of peak sucrose storage. Plant Biol. 17, 608-617.doi: 10.1111/plb. 12276

Chen, S. F., Liang, K., Yin, D. M., Ni, D. A., Zhang, Z. G., and Ruan, Y. L. (2016). Ectopic expression of a tobacco vacuolar invertase inhibitor in guard cells confers drought tolerance in Arabidopsis. J. Enzyme Inhib. Med. Chem. 31, 1381-1385. doi: 10.3109/14756366.2016.1142981

FAOSTAT (2014). Food and Agriculture Organization of the United Nations. Available online at: http://www.fao.org/faostat/en/\#data/QC

Greiner, S., Krausgrill, S., and Rausch, T. (1998). Cloning of a tobacco apoplasmic invertase inhibitor. Proof of function of the recombinant protein and expression analysis during plant development. Plant Physiol. 116, 733-742. doi: $10.1104 /$ pp.116.2.733

Greiner, S., Rausch, T., Sonnewald, U., and Herbers, K. (1999). Ectopic expression of a tobacco invertase inhibitor homolog prevents cold-induced sweetening of potato tubers. Nat. Biotechnol. 17, 708-711. doi: 10.1038/10924

Hatch, M. D., and Glasziou, K. T. (1963). Sugar accumulation cycle in sugarcane. II. Relationship of invertase activity to sugar content and growth rate in storage tissue of plants grown in controlled environments. Plant Physiol. 38, 344-348. doi: $10.1104 /$ pp.38.3.344

Hiller, K., Grote, A., Scheer, M., Münch, R., and Jahn, D. (2004). PrediSi: prediction of signal peptides and their cleavage positions. Nucleic Acids Res. 32, W375-W379. doi: 10.1093/nar/gkh378

Hothorn, M., den Ende, W., Lammensc, W., Rybina, V., and Scheffzeka, K. (2010). Structural insights into the $\mathrm{pH}$-controlled targeting of plant cell-wall invertase by a specific inhibitor protein. Proc. Natl. Acad. Sci. U.S.A. 107, 17427-17432. doi: $10.1073 /$ pnas. 1004481107
Hothorn, M., Wolf, S., Aloy, P., Greiner, S., and Scheffzek, K. (2004). Structural insights into the target specificity of plant invertase and pectin methyl esterase inhibitory proteins. Plant Cell 16, 3437-3447. doi: 10.1105/tpc.104.025684

Jackson, M. A., Nutt, K. A., Hassall, R., and Rae, A. L. (2010). Comparative efficiency of subcellular targeting signals for expression of a toxic protein in sugarcane. Funct. Plant Biol. 37, 785-793. doi: 10.1071/FP09243

Jackson, M. A., Rae, A. L., Casu, R. E., Grof, C. P. L., Bonnett, G. D., and Maclean, D. J. (2007). A bioinformatic approach to the identification of a conserved domain in a sugarcane legumain that directs GFP to the lytic vacuole. Funct. Plant Biol. 34, 633-644. doi: 10.1071/FP07024

Jaynes, T. A., and Nelson, O. E. (1971). An invertase inactivator in maize endosperm and factors affecting inactivation. Plant Physiol. 47, 629-634. doi: 10.1104/pp.47.5.629

Jin, Y., Ni, D. A., and Ruan, Y. L. (2009). Posttranslational elevation of cell wall invertase activity by silencing its inhibitor in tomato delays leaf senescence and increases seed weight and fruit hexose level. Plant Cell. 21, 2072-2089. doi: $10.1105 /$ tpc.108.063719

Jones, D. T. (1999). Protein secondary structure prediction based on position specific scoring matrices. J. Mol. Biol. 292, 195-202. doi: 10.1006/jmbi.1999.3091

Krausgrill, S., Greiner, S., Koster, U., Vogel, R., and Rausch, T. (1998).In transformed tobacco cells the apoplasmic invertase inhibitor operates as a regulatory switch of cell wall invertase. Plant J. 13, 275-280. doi: 10.1046/j.1365-313X.1998.00026.x

Kuijper, J. (1915). DeGroei van Bladschijf, Bladscheede em Stengel van het suikerriet. Arch Suikerind Ned Indië 23, 528-556.

Kumar, S., Stecher, G., and Tamura, K. (2016). MEGA 7: Molecular evolutionary analysis version 7.0 for bigger datasets. Mol. Biol. Evol. 33, 1870-1874. doi: $10.1093 / \mathrm{molbev} / \mathrm{msw} 054$

Kursanov, A. L., Dubinina, I. M., and Burakhanova, E. A. (1971). A natural inhibitor of invertase from sugar beet roots. Fiziol. Rast. 18, 568-574.

Laemmli, B. K. (1970). Cleavage of structural proteins during the assembly of the head of bacteriophage T4. Nature 223, 680-685. doi: 10.1038/227680a0

Ma, H., Albert, H. H., Paull, R., and Moore, P. H. (2000). Metabolic engineering of invertase activities in different sub-cellular compartments affects sucrose accumulation in sugarcane cells. Aust. J. Plant Physiol.27, 1021-1030. doi: 10.1071/PP00029

McCormick, A. J., Cramer, M. D., and Watt, D. A. (2006). Sink strength regulates photosynthesis in sugarcane. New Phytol. 171, 759-770. doi: 10.1111/j.1469-8137.2006.01785.x

McCormick, A. J., Watt, D. A., and Cramer, M. D. (2009). Supply and demand: sink regulation of sugar accumulation in sugarcane. J. Exp. Bot. 60, 357-364. doi: $10.1093 /$ jxb/ern310

Moore, P. H. (1987). “Anatomy and morphology”, in Sugarcane Improvement Through Breeding, ed D. J. Heinz (Amsterdam:Elsevier), 85-142.

Moore, P. H. (1995). Temporal and spatial regulation of sucrose metabolism in the sugarcane stem. Aust. J. Plant Physiol. 22, 661-679. doi: 10.1071/PP9950661

Ni, D. A. (2012). Role of vacuolar invertase in regulating Arabidopsis stomatal opening. Acta Physiol. Plant. 34, 2449-2452. doi: 10.1007/s11738-012-1036-5

Ohyama, A., Ito, H., Sato, T., Nishimura, S., Imai, T., and Hirai, M. (1995). Suppression of acidic invertase activity by antisense RNA modifies the sugar composition of tomato fruit. Plant Cell Physiol. 36, 369-376. doi: 10.1093/oxfordjournals.pcp.a078769

Palaniswamy, H., Divya, P. S., Chakravarthi, M., Philip, A., Petchiyappan, A., and Narayanan, S. (2016). Vacuolar targeting of r-proteins in sugarcane leads to higher levels of purifiable commercially equivalent recombinant proteins in cane juice. Plant Biotech. J. 14, 791-807. doi: 10.1111/pbi.12430

Patel, M., Johnson, J. S., Brettell, R. I. S., Jacobsen, J., and Xue, G. P. (2000). Transgenic barley expressing a fungal xylanase gene in the endosperm of the developing grains. Mol. Breed. 6, 113-123. doi: 10.1023/A:1009640427515

Petersen, T. N., Brunak, S., von Heijne, G., and Nielsen, H. (2011). SIGNALP 4.0: discriminating signal peptides from transmembrane regions. Nat. Methods. 8 , 785-786. doi: 10.1038/nmeth.1701

Pressey, R. (1968). Invertase inhibitors from red beet, sugar beet and sweet potato roots. Plant Physiol. 43, 1430-1434. doi: 10.1104/pp.43.9.1430

Qin, G., Zhu, Z., Wang, W., Cai, J., Chen, Y., Li, L., et al. (2016). A tomato vacuolar invertase inhibitor mediates sucrose metabolism and influences fruit ripening. Plant Physiol. 172, 1596-1611. doi: 10.1104/pp.16.01269 
Rae, A. L., Casu, R. E., Perroux, J. M., Jackson, M. A., and Grof, C. P. (2010). A soluble acid invertase is directed to the vacuole by a signal anchor mechanism. J. Plant Physiol. 168, 983-989. doi: 10.1016/j.jplph.2010.11.003

Rae, A. L., Grof, C. P. L., Casu, R. E., and Bonnett, G. D. (2005). Sucrose accumulation in the sugarcane stem: pathways and control points for transport and compartmentation. Field Crops Res. 92, 159-168. doi: 10.1016/j.fcr.2005.01.027

Rae, A. L., Jackson, M. A., Nguyen, C. H., and Bonnett, G. D. (2009). Functional specialization of vacuoles in sugarcane leaf and stem. Trop. Plant Biol. 2, 13-22. doi: 10.1007/s12042-008-9019-9

Rausch, T., and Greiner, S. (2004). Plant protein inhibitors of invertases. Biochim. Biophys. Acta 1696, 253-261. doi: 10.1016/j.bbapap.2003.09.017

Reca, I. B., Brutus, A., D’Avino, R., Villard, C., Bellincampi, D., and Giardina, T. (2008). Molecular cloning, expression and characterization of a novel apoplasticinvertase inhibitor from tomato (Solanum lycopersicum) and its use to purify a vacuolar invertase. Biochimie 90, 1611-1623. doi: 10.1016/j.biochi.2008.04.019

Roitsch, T., and González, M. C. (2004). Function and regulation of plant invertases: sweet sensations. Trends Plant Sci. 9, 606-613. doi: 10.1016/j.tplants.2004.10.009

Rossouw, D., Bosch, S., Kossmann, J., Botha, F. C., and Groenewald, J. H. (2007). Down-regulation of neutral invertase activity in transgenic sugarcane cell suspension cultures leads to a reduction in respiration and growth and an increase in sucrose accumulation. Funct. Plant Biol. 34, 490-498. doi: 10.1071/FP06214

Sacher, J. A., Hatch, M. D., and Glasziou, K. T. (1963). Sugar accumulation cycle in sugarcane. III. Physical and metabolic aspects in immature storage tissues. Plant Physiol. 38, 348-354. doi: 10.1104/pp.38.3.348

Sander, A., Krausgrill, S., Greiner, S., Weil, M., and Rausch, T. (1996). Sucrose protects cell wall invertase but not vacuolar invertase against proteinaceous inhibitors. FEBS Lett. 385, 171-175. doi: 10.1016/0014-5793(96)00378-X

Sanger, F., Nicklen, S., and Coulson, A. R. (1977). DNA sequencing with chain-terminating inhibitors. Proc. Natl. Acad. Sci. U.S.A. 74, 5463-5467. doi: $10.1073 /$ pnas.74.12.5463

Schwimmer, S., Makower, R. U., and Rorem, E. S. (1961). Invertase and invertase inhibitor in potato. Plant Physiol. 36, 313-316. doi: 10.1104/pp.36.3.313

Shaw, L. M., McIntyre, C. L., Gresshoff, P. M., and Xue, G. P. (2009). Members of the Dof transcription factor family in Triticum aestivum are associated with light-mediated gene regulation. Funct. Integr. Genomics 9, 485-498. doi: 10.1007/s10142-009-0130-2

Singh, P., Solomon, S., Shrivastava, A. K., Prajapati, C. P., and Singh, R. K. (2008). Sucrose loss and change in enzymes activities in harvested stored cane at high ambient temperature. Sugar Tech. 11, 181-184. doi: 10.1007/s12355-009-0028-2

Siqueira, G. F., Pierre, J. S., El Tahchy, A., Glassop, D., Singh, S., Bonnett, G. D., et al. (2015). Sugarcane seed composition and changes during artificial ageing. Crop Pasture Sci. 66, 1180-1189. doi: 10.1071/CP 15009

Solomon, S. (2009). Post-harvest deterioration in sugarcane. Sugar Tech. 11, 109-123. doi: 10.1007/s12355-009-0018-4

Sonnewald, U., Brauer, M., von Schaewen, A., Stitt, M., and Willmitzer, L. (1991). Transgenic tobacco plants expressing yeast derived invertase in the cytosol, vacuole or the apoplast: a powerful tool for studying sucrose metabolism and sink/source interactions. Plant J. 1, 95-106. doi: 10.1111/j.1365-313X.1991.00095.x

Suresha, G. S., Mahadevaiah, C., and Appunu, C. (2017). "Biotechnological interventions for improving sucrose accumulation in sugarcane," in Sugarcane Biotechnology: Challenges Prospects, ed C. Mohan, (Cham: Springer International Publishing), 111-122.
Tang, G. Q., Lüscher, M., and Sturm, A. (1999). Antisense repression of vacuolar and cell wall invertase in transgenic carrot alters early plant development and sucrose partitioning. Plant Cell 11, 177-189. doi: 10.1105/tpc.11.2.177

Tang, X., Su, T., Han, M., Wei, L., Wang, W., Yu, Z., et al. (2017). Suppression of extracellular invertase inhibitor gene expression improves seed weight in soybean (Glycine max). J. Exp. Bot. 68, 469-482. doi: 10.1093/jxb/erw425

Tauzin, A. S., and Giardina, T. (2014). Sucrose and invertases, a part of the plant defense response to the biotic stresses. Front. Plant Sci. 5:293. doi: $10.3389 /$ fpls.2014.00293

von Schaewen, A., Stitt, M., Schmidt, R., Sonnewald, U., and Willmitzer, L. (1990). Expression of yeast-derived invertase in the cell wall of tobacco and Arabidopsis plants leads to accumulation of carbohydrate and inhibition of photosynthesis and strongly growth influences growth and phenotype of transgenic tobacco plants. EMBO J. 9, 3033-3044.

Wang, J., Nayak, S., Koch, K., and Ming, R. (2013). Carbon partitioning in sugarcane (Saccharum species). Front. Plant Sci. 4:201. doi: 10.3389/fpls.2013.00201

Watt, D. A., McCormick, A. J., Govender, C., Carson, D. L., Cramer, M. D., Huckett, B. I., et al. (2005). Increasing the utility of genomics in unravelling sucrose accumulation. Field Crops Res. 92, 149-158. doi: 10.1016/j.fcr.2005.01.012

Weil, M., Krausgrill, S., Schuster, A., and Rausch, T. (1994). A 17 $\mathrm{kDaNicotianatabacum}$ cell-wall peptide acts as an in-vitro inhibitor of the cell-wall isoform of acid invertase. Planta 193, 438-445. doi: 10.1007/BF00201824

Whittaker, A., and Botha, F. C. (1997). Carbon partitioning during sucrose accumulation in sugarcane internodal tissue. Plant Physiol. 115, 1651-1659. doi: $10.1104 /$ pp.115.4.1651

Wu, L., and Birch, R. G. (2007). Doubled sugar content in sugarcane plants modified to produce a sucrose isomer. Plant Biotechnol. J. 5, 109-117. doi: 10.1111/j.1467-7652.2006.00224.X

Xu, X., Hu, Q., Yang, W. N., and Jin, Y. (2017). The roles of call wall invertase inhibitor in regulating chilling tolerance in tomato. BMC Plant Biol. 17:195 doi: $10.1186 /$ s12870-017-1145-9

Xue, G. P. (2002). Characterization of the DNA-binding profile of barley HvCBF1 using an enzymatic method for rapid, quantitative and highthroughput analysis of the DNA-binding activity. Nucleic Acids Res. 30:e77. doi: 10.1093/nar/gnf076

Zhu, Y. J., Komor, E., and Moore, P. H. (1997). Sucrose accumulation in the sugarcane stem is regulated by the difference between the activities of soluble acid invertase and sucrose phosphate synthase. Plant Physiol. 115, 609-616. doi: 10.1104/pp.115.2.609

Zuma, B., Dana, M. B., and Dongfang Wang, D. (2018). Prolonged expression of a putative invertase inhibitor in micropylar endosperm suppressed embryo growth in Arabidopsis. Front. Plant Sci. 9:61. doi: 10.3389/fpls.2018.00061

Conflict of Interest Statement: The authors declare that the research was conducted in the absence of any commercial or financial relationships that could be construed as a potential conflict of interest.

The reviewer JN and handling Editor declared their shared affiliation.

Copyright (c) 2018 Shivalingamurthy, Anangi, Kalaipandian, Glassop, King and Rae. This is an open-access article distributed under the terms of the Creative Commons Attribution License (CC BY). The use, distribution or reproduction in other forums is permitted, provided the original author(s) and the copyright owner are credited and that the original publication in this journal is cited, in accordance with accepted academic practice. No use, distribution or reproduction is permitted which does not comply with these terms. 